\title{
Textile industry participation in engineering education is the need of the hour in developing textile industry
}

\section{Preamble}

Centre for textile functions with new concept in engineering education by textile industry participation in education

There is wide gap between the Technology available in the Industry and Technology practical's conducted in the educational Institutes. Idea is to bridge the gap between the industry and education by giving practical exposure to the students in present Technology in the Industry.

India is producing large pool of scientist and technologist from various field Viz; EXTC, IT, computer, Mechanical Civil Textiles, Pharmacy etc. NMIMS has established few campuses in India.

Industry expectation from the fresh graduates is application of present scientific knowledge to develop innovative technology and use new technology by creating infrastructure, goods, and services for only small percentage of the Engineers and professional are able to meet this expectation since there is wide gap between Industry and academy in India. Almost 90\% need training and work exposure.

Growth of nation is measured in terms of annual GDP. India has to go for large scale manufacturing in Engineering Industries. To support this India is promoting investment in infrastructure development, application of electronic, computer \& IT in all sectors to promote Engineering Industries. Any new Technology application needs Trained Technical man power. Establishment of new Industries needs large pool of trained technical personnel's. Hence large no of educational Institutes are established with private sector participation. These educational institute need to associate with Industry for practical exposure to develop basic technical knowledge in students to work in different Technology and projects. Hence create an opportunity for their talent pool in the country by Industry -Institute linkage.

\section{Industry - Institute linkage}

To bridge the gap between Industry and education it is proposed to seek cooperation in following area:

\section{To impart basic knowledge to the technical graduates to work in present technology}

Methodology: To develop curriculum to impart basic practical knowledge during the course curriculum to work in different profession Viz, Research and Development / Production /Planning/ Design and Development/Maintenance/Marketing and servicing.

Expected outcome; Students will know about their profession, opportunity in their profession and hence develop skills required for employment in these sectors.
Volume 4 Issue I - 2018

PP Raichurkar

Associate Dean, CTF MPSTME SVKMS NMIMS deemed to be university, India

Correspondence: PP Raichurkar, Associate Dean, CTF MPSTME SVKMS NMIMS deemed to be university, Mukesh Patel Technology Park, Babulde, Bank of Tapi River, Mumbai-Agra Road (NH3), Shirpur-425405, Maharashtra, India, Tel 9923946044 , Email PP.Raichurkar@nmims.edu

Received: December 21, 2017 | Published: February 06, 2018

Development of the knowledge centers in campus to give practical exposure to present Science \& Technology developments by formulating training program with industry to produce skilled technical personnel with core competency in their subject to match industry requirement

Methodology: To impart practical knowledge to students by using the existing laboratory to develop skills required in application of the present Technology in the different Domain. Hence, Development of the knowledge centers in campus by Industry association for skill development programs to student to work in present core domain of the Industry.

Expected results: Development of the Technical personnel's with core competency.

\section{Academy -industry collaboration for industry research and academic excellence}

Methodology: Higher studies programs for innovative research: Higher studies in foreign universities collaboration. Foreign university internship, Students exchange program. Staff exchange program. Promotion of Innovative Industry research in developed country and Institutes of Higher standards in academic research in collaboration with Industry.

Transfer of technology to industry by industry-institute collaborative educational training program.

Methodology: Mentoring of the student's projects to develop Innovative Research /Product/Technology /Processes by association of Teachers with Industry Mentors. Develop mutually beneficial programs for the benefit of both Industry \& Educational Institute. 
To collaborate with machinery manufacturers; supply and delivery new technology along with trained manpower

Methodology: Technological Development in the machine/process to be taught to the students

Development of the training module by Industry participation. Develop concept Green Technology adoption, Sustainable Technology development, Low energy consumption. Demonstration of new Technology in campus. By developing thrust areas to work in collaboration with Industry department wise, we can develop technical ability in students by way of Publication / Product development/Patent etc. can attract Industries to campus for placement.

Centre for textile functions is emerging as one of the best textile institute by textile industry participation in training for skills on production floor

CTF NMIMS is emerging as one of the top Textile Institute as an integral part of the Textile Park set up in rural India under leadership of Shri Amrish R Patel Chancellor NMIMS deemed to be university. The programs are conceived by Top Textiles Industry Executives participation as Board Members in CTF with a road map to make CTF a role model Textile Institute in next 10years under NMIMS with Technical people working in the Major corporate Textile Industry for Innovation/Business Development/Marketing support for Textile Industry Business development in India by producing Technical Human capital to work for the Top textile Industry in the world.

NMIMS management Schools have groomed many Top corporate Textile industry Managers. These management Graduates are running Textile Production units as entrepreneurs and Technical Managers in corporate Textile Industries and they are supporting development of practically trained technical personnel to work in Textile Industry. This is possible by Textile Industry participation in Textile Education. This is role model Textile education centre in India with Textile Industry participation. This has transformed rural youth to become Engineers on production floor with high performance Following Industry collaboration model is being adopted to formulate all the Diploma and Degree program to prepare Technical human capital to work for the Textile Industry (Figure 1).

\section{CTF NMIMS white paper - how automation required} in textile industry

Textile industry is a sub-set of product-based industry. Hence, it will have all the ingredients of a product based industry, namely:

a. Product development/R\&D/Design

b. Process engineering/Pre-production/Process development

c. Production/Manufacturing

d. Testing/Final Q.C/

e. Maintenance of Capital equipment used in Production

f. Servicing

Each of the above has its own uniqueness for an upcoming Textile engineer.

i. $R \& D$ requires use of simulation packages from Textile engineers to simulate how Textile machinery uses Electronic Gadgets EMC and affects the electronic circuits (e.g. valve-timing). Optimize the process parameters for best performance of the Machinery used in large scale manufacturing process.

ii. Process engineering involves assisting the shop-layout designers in creating effective work-flow of material (assembly etc.) on a transfer line, which uses extensive automation and automation circuitry. Assisting in creating cost effective transfer lines is the main effort by using hardware/software/pneumatics/hydraulics etc.

iii. Production involves giving output as required in terms of numbers per shift. Effort required is to assist in creating monitoring network for measuring output of various parameters. Textiles products have lots variations in manufacturing process Small and even trending software makes monitoring simpler.

iv. Testing at the end of production is to ensure that output is meeting expectations. Hardware/software is required to measure only selected parameters independently (other than that done by Production) to assure quality to the end customer.

v. Maintenance of all above equipment is a job by itself where an engineer learns the essentials of all the above equipment.

vi. Servicing Textile Machinery is getting highly automated today. Simple example is knotting, beam gaiting and replacement of the beam and change in quality in the various products are familiar. Lots of inputs are available in an inquisitive mind of an Textile Engineer with Multi-Tasking abilities in electronic gadget applications by engineer will assist in learning all facets of the Textile industry in a career-life-time and enable the engineer to learn, grow and earn respect in the industry. He will gain recognition in industry forums due to his knowledge and contribution and be valued by society.

\section{Industry Collaboration Maturity Model}

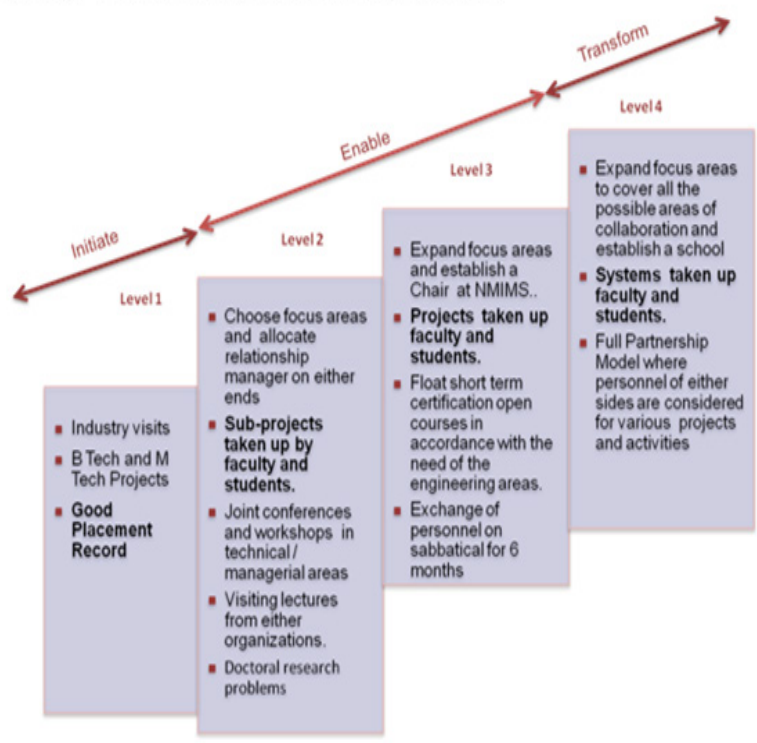

Figure I Industry collaboration maturity model.

NMIMS strategy: rural youth employment generation program by ctf nmims deemed to be university

a. CTF is feather in the cap of the SVKMS NMIMS deemed to 
be university for the socio economic development of the cotton growing farmer's children to become entrepreneurs and to provide employment to technically trained rural youths. Mission is to make shirpur Textile Park, hub of top Textile Industry in the world with latest Technology required in large scale manufacturing.

b. CTF Diploma programs DTT and PGDTP students are in good demand for employment in Textile Industry M/S Anubha, Welspun, Alok, Raymond's Tridents Century and Mafatlal etc. In last two years CTF has initiated B. Tech textiles with clear mandate to promote Industry driven practical research. First Batch is being dedicated to Textile Industry in 2018. All the B. Tech students are doing Industry useful work leading to problem solving abilities in the present Technology in Textile Industry. Staff and Students are engaged in Innovative Research projects supported by the Textile Industry. Each individual B. Tech students will Publish their work in impact factor Journal under the supervision of the Senior Technical mangers and staff of CTF.

c. CTF is practicing Textile Industry participation for continuous up-gradation of the skills in Technical people for, usage of new technology in developing advance Textile Materials and Textile product development as essential part of the Textile Industry to be in competition in International Market to produce and offer value added quality products. This is need of the hour for Indian Textile Industry for the development of the Textile Industry in India because it is facing acute shortage of technically trained personals to work in large scale manufacturing.

d. CTF is able to develop new concept of "See and learn and work and learn". Since Welspun, Alok, Raymond, Trident Century and Maral etc. are continuously modernizing and coming up with several modernization programs for automation and large scale manufacturing in rural India Centre for Textile Functions is covering complete mismatch between Technology available in educational Institutes and Modern Corporate Technology by incorporation Training in Industry. Their participation is major turning point in giving Practical exposure to diploma and degree students in present technology.

e. Textile Industry Technicians from All branches of Engineering Viz Textile, Mechanical, IT computer Instrumentation are Trained in optimum utilization of the Textile Technology utilization in manufacturing. With help Bosch Rexroth automation Centre in MPTP campus. Based on this there is a huge demand for Training Engineers from all branches who are working in Textile Industry as Technicians in Major companies are Welspun Alok LNJB Century and Garware.

\section{Important achievement of CTF in last two years towards NMIMS strategy}

Employment in opportunity for BSc chemistry graduates: This is one good opportunity for the youth for employment in Textile Industries created under NMIMS in rural India. The social back ground of the youths in India clearly indicates that they need training in skills development $85 \%$ of the youth do not go beyond SSC education. Further BSc chemistry Graduates struggle a lot in rural India. Based on the project training done by PGDTP students in the academic year 2015-16 they were selected in GIMA Textile with good starting salary package. The work is published in Scopus index journal. The work done by these students was presented to Birla century Bharuch. Outcome of this presentation by students Lead to selection of junior batch students for Internship in Birla century during project training by stipend of Rs 8000/-. PGDTP students entire prescribed fee for two years 48000 is reimbursed to students before completion of the curriculum. This is creditable achievement for CTF NMIMS for the vision Shri Amrish R Patel has for BSc graduates in rural India. This program with NMIMS support can be backbone for Textile wet processing Industry it needs nearly 5000 fresh technical people. CTF is producing hardly 10 to 12 students. BSc chemistry graduates struggle for employment and career progression in different domain.

To train SSC, PUC $10+2$ and BSC chemistry youth CTF has developed training programs as an integral part of the Industry. This practical exposure training with excellent support from Major corporate Textile Industry to train their own Technicians. Technical personnel joining the present Technology needs lot of Industry time to learn and adopt. This is the area in which it is proposed to seek Textile Industry participation in education to train and groom Diploma, UG. $\mathrm{PG}$ and $\mathrm{PhD}$ programs under NMIMS in next 10years. This is mainly sought for practical exposure and practicals in present Technology and methodology to adopt Technological developments in working for the process and product development activities.

Industry participation in Education is need of the Textile Industry to develop Technical Human capital to work in automation.

\section{CTF is offering following programs (Table 1)}

Above programs are established in CTF with Textile Industry in-plant training and has prepared 300 diploma graduates working in different Textile Industries in India. CTF has developed Industry driven project works leading students work publication in Impact factor Journals As on date there are 25 publications 2014 to 2017 period has published approximately 11 Scopus articles by Individual Students with staff and Mentor from Textile Industry.

Table I CTF is offering programs

\begin{tabular}{lll}
\hline S. no & CTF is offering following programs & Duration \\
\hline I & Diploma in Textile Technology & 3 years \\
2 & Post Graduate Diploma in Textile wet processing & 2 years \\
3 & B.Tech Textiles & 4 years \\
\hline
\end{tabular}

Main High light of the programs is $100 \%$ of the students are Performing Practical work under CTF staff and Industry senior Technical personnel in present Technology. The work done is published in impact factor journal. CTF has started IJTEP journal in academic year 2014 and this journal has ISSN 23953578 and UGC number 45185 . Thus developing new teaching learning pedagoy for practical's in present Technology in Industries (Table 2).

Indian Textile Industry needs large number of Technical personnel with basic multi-tasking abilities to work on the production floor. For this Textile Industry needs to promote \& participate in developing Textile Education and Research as integral part of the Textile Industry in rural India. Compared to Top Textile Engineering Institutes in the world, India needs to adopt and develop system in Textile institutes as is being adopted in developed and advanced Institutes all over the developed world to establish good Textile university system in India. .NMIMS is moving towards preparing Industry driven Innovative Techno commercial Mangers to manage large scale manufacturing in 
Engineering and allied Textile and Pharma Industries in the country. Large number of NMIMS alumina are Mangers heading Textile Industry business all over India in different domain Viz Production, Planning Marketing and Market development in Top corporate Textile
Industry. CTF has developed automation program for Textile Industry Technicians. Curriculum for B. Tech has this advantage compared to any Textile Institute in India. Textile Industry needs such Trained Technical personnel.

Table 2 Performing Practical work under CTF staff and Industry senior Technical personnel in present Technology

\begin{tabular}{|c|c|c|c|c|c|c|}
\hline \multicolumn{6}{|c|}{ CTF students publications under the guidance of staff and industry mentors } & \multirow[t]{2}{*}{ Scopus index } \\
\hline \multicolumn{6}{|c|}{ CTF international publications } & \\
\hline $2014-15$ & & & 2015 & & & \multirow{5}{*}{4} \\
\hline DTT & PGDTP & B. Tech Textile & DTT & PGDTP & B. Tech Textile & \\
\hline 7 & 1 & 0 & 9 & I & 6 & \\
\hline \multicolumn{6}{|c|}{ CTF national publications } & \\
\hline $2014-15$ & & & 2015 & & & \\
\hline DTT & PGDTP & B. Tech Textile & DTT & PGDTP & B. Tech Textile & \multirow[t]{2}{*}{7} \\
\hline 4 & 0 & 0 & 4 & 0 & 0 & \\
\hline
\end{tabular}

\section{Conclusion}

Textile Industry needs to modernize decentralized sector in India. To compete in International and domestic market India needs to atomize and optimize manufacturing process with an inquisitive mind of Textile engineers who has multi-Tasking skills developed by Textile Industry participation. Grooming and training students during execution Training /project exclusively under competent Technical personnel from the Textile Industry needs to be developed for each Technology to optimize performance.

\section{Acknowledgements}

None.

\section{Conflict of interest}

Author declares there is no conflict of interest.

\section{References}

1. Ramachandran M, Rishabh Bhargava, Pramod Raichurkar. Effect of nanotechnology in enhancing mechanical properties of composite materials. International $J$ Textile Engineering \& Processes. 2016;2(1):59-63.

2. Deepali Mor, Sahas Bansal, M Ramachandran, et al. Review on Antibacterial, Antiviral, and Antifungal Properties of Natural Diapers and its Effect on Dermatitis. International J Pharm Tech Research. 2015;8(10):40-46.

3. Sneha Khairnar, Pramod Raichurkar, Pranjali Chandurkar, et al. Role of Merchandiser to optimize Manufacturing cost. $J$ Textile Association. 2015;76(3):161-164.

4. Pramod Raichurkar, Pradeep waychal. Running a Successful Textile Diploma Course in a Remote Indian Town a Case Study. J Engineering Education Transformation. 2015;29(113):38-42.
5. Pramod Raichurkar, Ramachandran M. Importance of Teaching Automation as an integral part of Engineering at Educational Institutes. International J Textile Engineering \& Processes. 2015;1(3):18-21.

6. Pramod Raichurkar, Updeep Singh, Tushar Patil, et al. Cotton Weaving - A New Business opportunities and diversification in Cotton weaving. International J Textile Engineering \& Processes. 2015;1(2):11-15.

7. Pramod Raichurkar, Shamsundar HR. On wrinkle recovery of the crepe silk fabrics. Indian Textile J. 1989. p. 54-59.

8. Pramod Raichurkar, Shamsundar HR. Effect of twist on the crepe silk fabrics. Indian Textile J. 1991. p. 216-226.

9. Hadimani VV, Halliyal VG, Pramod Raichurkar, et al. Silk wet processing in China. Indian textile J. 1998.

10. Pramod Raichurkar. Problems of the silk weaving industry in India. Indian Textile J. 1999. p. 82-89.

11. Hayavadana J, Pramod Raichurkar. Handle of alkaline oxidized p/c dress materials. Textile Asia. 2003. p. 56-65.

12. Renukadevi R, Raichurkar PP, Subramaniam V. Effect of seam on the draping quality of the fabric. International conference on Advances in Textiles, Machinery, Nonwoven and Technical Textiles Kummarguru college of Technology. Coimbatore, India; 2007.

13. Raichurkar PP. Supply Chain Management in Silk Industries, Managerial workshop Under Integrated Handloom Training Project (IHTP) Funded by Ministry of Textiles Government of India. 2005.

14. Kauvery Bai S, Raichurkar PP, Subramaniam V. Application of peach finish on mechanical properties of crepe silk and its effect on washing and dimensional stability, The 20th Congress of the International Sericulture Commission ISCC 2005. Central Silk Board Government of India, Bangalore, India; 2005.

15. Raichurkar PP. Importance of Silk Testing. Ncute programme, Osmania University, Hyderabad, India; 2004. 